\title{
39. CERIUM ANOMALIES IN WESTERN INDIAN OCEAN CENOZOIC CARBONATES, LEG 115
}

\author{
Y.-G. Liu $^{2}$ and R. A. Schmitt ${ }^{3}$
}

\begin{abstract}
We subjected 18 carbonate samples <1-46 Ma in age from Holes 706A, 707A, 708A, 709C, 710A, and 711A on or near the Mascarene Plateau and Madingley Rise and from Holes 712A, 713A, and 716A on or near the Chagos BankMaldives Ridge to instrumental neutron activation analysis to measure 32 major, minor, and trace elements and to determine the Ce anomalies $\left(\mathrm{Ce}^{\mathrm{A}^{*}}\right)$ in the carbonates relative to NASC (North American Shale Composite). Five carbonates, 32-46 Ma, yielded an average $\mathrm{Ce}^{\mathrm{A}^{*}}$ value of $0.14 \pm 0.05$, corrected for small $(0.1 \%-1.8 \%)$ detrital clay particulates. This $\mathrm{Ce}^{\mathrm{A}^{*}}$ value is considered to represent the inferred $\mathrm{Ce}^{\mathrm{A}}$ value in the western Indian Ocean during the 32-46-Ma interval and compares to an average $\mathrm{Ce}^{\mathrm{A}}$ value of $0.05 \pm 0.02$ in the Pacific Ocean during the past $\sim 35 \mathrm{Ma}$ and from 93 to $97 \mathrm{Ma}$. These inferred $\mathrm{Ce}^{\mathrm{A}}$ values are consistent with the $\mathrm{Ce}$ redox formulation proposed previously by the authors, which indirectly relates the $\mathrm{Ce}^{\mathrm{A}}$ of seawater to the $\mathrm{pH}$ of the mixed layer.

The higher $\mathrm{Ce}^{\mathrm{A}^{*}}$ values of $0.23-0.66$ in 11 carbonates, $<1-30 \mathrm{Ma}$, indicate an inhibition of $\mathrm{Ce}^{+3}$ oxidation to $\mathrm{Ce}(\mathrm{OH})_{4}$ in seawater during this interval. This observation is consistent with an enhanced transport of decayed organic debris into the Indian Ocean from the Himalayan Mountains, thereby providing a more reducing seawater environment. The postulated prominence of the Himalayas at $\sim 30 \mathrm{Ma}$ is consistent with the ODP Leg 116 observations that the voluminous sedimentation rates in the eastern Indian Ocean from the Bengal Fan existed for the past $\geq 24 \mathrm{Ma}$. An accelerated rise of the Himalayas may have commenced $\sim 33-35 \mathrm{Ma}$.
\end{abstract}

\section{INTRODUCTION}

In a series of paleoceanographic investigations at our laboratory, we have measured via instrumental neutron activation analysis (INAA) variations of $\mathrm{Ce}$ anomalies $\left(\mathrm{Ce}^{\mathrm{A}} \equiv \mathrm{Ce}-\mathrm{ob}\right.$ served abundances normalized to North American Shale Composite (NASC)/Ce interpolated abundances between $\mathrm{La}$ and $\mathrm{Nd}$ ) in $>250$ global marine carbonates to study paleoceanic redox conditions and atmospheric $\mathrm{P}_{\mathrm{CO}_{2}}$ changes over the past 470 Ma. For example, Liu and Schmitt (1984) measured 32 major, minor, and trace elements in 48 sediment samples from the $574-$ $\mathrm{m}$ Deep Sea Drilling Project (DSDP) Hole 525A ( 70-Ma span) on the Walvis Ridge in the eastern South Atlantic. Their studies indicated that changes in Ce concentrations in pure carbonates, relative to North American Shale Composite (NASC) (Gromet et al., 1984), reflected the relative concentrations of the trivalent rare earth elements (REE), and particularly the contiguous light rare earth elements (LREE), $\mathrm{La}, \mathrm{Ce}, \mathrm{Pr}$, and $\mathrm{Nd}$ in seawater.

Oxidation of an appreciable fraction $(\sim 80 \%)$ of $\mathrm{Ce}^{+3}$ to a colloidal $\mathrm{Ce}^{+4}$ hydroxide (Goldberg, 1961; Goldberg et al., $1963)$ or to highly insoluble $\mathrm{Ce}(\mathrm{OH})_{4}$ (e.g., solubility product $\left.\mathrm{K}_{\mathrm{sp}} \sim 10^{-51}\right)$, followed by coprecipitation of $\mathrm{Ce}(\mathrm{OH})_{4}$ by other minerals, has been suggested by Ehrlich (1968) as a mechanism for achieving $\mathrm{Ce}^{+3}$ depletion in seawater relative to $\mathrm{La}^{+3}$ and $\mathrm{Nd}^{+3}$. The $\mathrm{Ce}^{\mathrm{A}}$ values of $0.35 \pm 0.04$ in pristine $\sim 1-58-\mathrm{Ma}$ marine carbonates, reported by Liu and Schmitt, compared with $\mathrm{Ce}^{\mathrm{A}^{*}}$ values of $0.28 \pm 0.04$ in fifteen $\sim 1-58$-Ma carbonates that were corrected for NASC-like detrital clay in the carbonates. Furthermore, they observed that the $\mathrm{Ce}^{\mathrm{A}}$ changed dramatically at $\sim 58 \mathrm{Ma}$ from 0.60 to 0.35 , which they attributed to a change from anoxic to oxic redox conditions (like the present) in the South Atlantic Ocean.

${ }^{1}$ Duncan, R. A., Backman, J., Peterson, L. C., et al., 1990. Proc. ODP, Sci. Results, 115: College Station, TX (Ocean Drilling Program).

2 Department of Chemistry and The Radiation Center, Oregon State University, Corvallis, OR 97331, U.S.A.

${ }^{3}$ Departments of Chemistry and Geosciences, The Radiation Center, and College of Oceanography, Oregon State University, Corvallis, OR 97331, U.S.A.
The $\mathrm{Ce}^{\mathrm{A}}$ changes reported by Liu and Schmitt (1984) were confirmed by Wang et al. (1986), who analyzed 90 calcareous/ clayey sediments obtained from the 1100 -m DSDP Holes $530 \mathrm{~A}$ and 530B ( 103-Ma span) in the southeastern corner of the Angola Basin near the eastern end of the Walvis Ridge. The Al contents from $0.12 \%$ to $10 \%$ in their sediment samples required appreciable corrections for the detrital clay contributions of REE in some samples to ascertain corrected $\mathrm{Ce}^{\mathrm{A}^{*}}$ values.

Testing the hypothesis that paleoredox conditions changed throughout the South Atlantic simultaneously at $\sim 55 \mathrm{Ma}, \mathrm{Hu}$ et al. (1988) analyzed 32 calcareous samples from the $1220-\mathrm{m}$ DSDP Holes 516 and 516F ( 86-Ma span) on the Rio Grande Rise in the western South Atlantic. Using regression analysis, they confirmed the hypothesis.

Studying redox changes $\left(\mathrm{P}_{\mathrm{CO}_{2}}-\mathrm{pH}\right)$ during the opening and subsequent development of the North Atlantic, Liu et al. (1988) analyzed ten calcareous sediments, five of which were limestones, from Holes 639A (90 m), 639D (293 m), and 638B $(430 \mathrm{~m})$ on the Galicia Margin. For two limestones of 1 and $120 \mathrm{Ma}$, we calculate $\mathrm{Ce}^{\mathrm{A}^{*}}$ values of 0.30 and 0.40 and for three $148-\mathrm{Ma}$ limestones, $\mathrm{Ce}^{\mathrm{A}^{*}}$ values of $0.86-1.01$. The former $\mathrm{Ce}^{\mathrm{A}^{*}}$ overlap those inferred for South Atlantic seawater. Furthermore, these data indicate redox changes for Ce occurred between 120 and $148 \mathrm{Ma}$ in the North Atlantic shallow seas separating Iberia and North America. The $\mathrm{Ce}^{\mathrm{A}^{*}}$ values in marine carbonates, corrected for NASC-like detrital clay particulates, from the South Atlantic (0-55 Ma) and from the North Atlantic (1-120 Ma), both under normal oxic conditions, agree within the dispersion of the $\mathrm{Ce}^{\mathrm{A}}$ values $0.18 \pm 0.12$ reported by $\mathrm{H} ø g d a h l$ et al. (1968) for six Atlantic seawater stations.

Cerium anomaly signatures in relatively pure marine carbonates have been measured by Liu et al. (1988) in the 750-m DSDP Hole 316 ( 80-Ma span), Central Pacific, and in $\sim 93-97-\mathrm{Ma}$ Laytonville Limestones (LL), presumably deposited in the eastern Pacific at $\sim 14^{\circ} \pm 5^{\circ} \mathrm{S}$ latitude. For eight Hole 316 limestones of $<1,7,35$, and $70-75 \mathrm{Ma}$ ages, $\mathrm{Ce}^{\mathrm{A}^{*}}$ values ranged from 0.04 to 0.13 , whereas in four LL samples, $\mathrm{Ce}^{\mathrm{A}^{*}}$ values averaged $0.034 \pm 0.018$. Recently, Jin and Schmitt (1989a) and Goles and Schmitt (1989) used INAA to obtain $\mathrm{Ce}^{\mathrm{A}^{*}}$ values in pristine marine carbonates from Hole $577(0->67 \mathrm{Ma})$. From 
the Michel et al. (1985) Hole 577B-1 data, they also calculated $\mathrm{Ce}^{\mathrm{A}^{*}}$ values in carbonates at and near the Cretaceous/Tertiary boundary and found that pristine Shatsky Rise carbonates yielded $\mathrm{Ce}^{\mathrm{A}^{*}}$ values ranging from 0.05 to 0.10 during normal Pacific oxic conditions (i.e., carbonates not specifically identified with a REE plus other trace element abundance peaks at and near the Cretaceous/Tertiary boundary). All of the abovecited $\mathrm{Ce}^{\mathrm{A}^{*}}$ values in Pacific carbonates agree well with the $\mathrm{Ce}^{\mathrm{A}}$ ranges reported by D. J. Piepgras and S. B. Jacobsen (pers. comm., 1988) of 0.043-0.105 for 400-6000 m Northwest Pacific Ocean columns.

All of the above observations and correlations prompted Liu et al. (1988) to suggest that the REE abundances in marine carbonates are proportional to the $\mathrm{REE}^{+3}$ contents in seawater $\left(\mathrm{Ce}^{+4} / \mathrm{Ce}^{+3} \sim 10^{-17}-10^{-15}\right.$ ) (Liu and Schmitt, 1984; DeBaar et al., 1985) and that the variety of normalized REE patterns in bulk marine carbonates are attributed to adsorption of some $\mathrm{REE}^{+3}$ onto the Fe-Mn-Al-Ti-oxyhydroxide coatings (Palmer, 1985) of sedimentary carbonate minerals and also to diagenetic growth of $\mathrm{REEPO}_{4}$ in the coatings (Wang et al., 1986; Liu et al., 1988). In addition, Liu et al. (1988) derived a Ce redox formulation that related the $\mathrm{Ce}$ concentration in seawater to the major controlling factors of $\mathrm{pH}$ and/or to the atmospheric $\mathrm{P}_{\mathrm{CO}_{2}}$ in equilibrium with seawater.

Continuing the reconnaissance of $\mathrm{Ce}^{\mathrm{A}}$ investigations in marine carbonates from the world's oceans and seas, we requested 18 pure western Indian Ocean marine carbonates that spanned the sedimentary age spectrum of $<1-46 \mathrm{Ma}$ and that were obtained from 9 holes drilled by Ocean Drilling Program (ODP) Leg 115, into the Nazareth Bank, Mascarene Plateau (706A); the saddle between the Seychelles and Saya de Malha banks, Mascarene Plateau (707A); the abyssal plain southwest of Madingley Rise (708A); Madingley Rise (709C, 710A, and 711A); the northern margin of the Chagos Bank (712A and 713A); and the Maldives Ridge (716A). With the exception of samples from Hole $713 \mathrm{~A}$ that were obtained via rotary core barrel (RCB) drilling, the other complete and undisturbed sedimentary samples were obtained by using the advanced hydraulic piston coring (APC) and extended core barrel (XCB) systems.

In our study of western Indian Ocean carbonates, we addressed the following problems: (1) to establish the $\mathrm{Ce}^{\mathrm{A}}$ and corrected $\mathrm{Ce}$ anomalies for their detrital clay particulate contents, $\mathrm{Ce}^{\mathrm{A}^{*}}$, in pristine carbonates spanning the age range of recovered cores, and to compare these $\mathrm{Ce}^{\mathrm{A}^{*}}$ values with other global marine carbonates of comparable ages; (2) to compare the paleoredox conditions, as reflected in Ce oxidation, in the Indian Ocean over the past $\sim 46 \mathrm{Ma}$ to those observed in the Atlantic and $\mathrm{Pa}$ cific oceans; and (3) to measure 32 elements, including $\mathrm{Ce}$, by means of INAA, to constrain the carbonate deposition and redox conditions over the past $\sim 46 \mathrm{Ma}$, which included effects of weathering the Himalayan Rise, and to search for any differences between carbonates deposited on the Mascarene PlateauMadingley Rise vs. the Chagos Bank-Maldives Ridge.

\section{EXPERIMENTAL METHODS}

Based on the Leg 115 (May-July 1987) inorganic geochemistry descriptions of the recovered marine carbonates, we requested and obtained the purest available samples from different sites with the highest $\mathrm{CaCO}_{3}$ wt \% consistent with a spectrum of paleontologic ages with estimated uncertainties of $5 \%-10 \%$. The samples were crushed in an agate mortar and freeze dried for $48 \mathrm{hr}$ to obtain consistent weights. Samples were weighed ( $\sim 900$ $\mathrm{mg}$ ) into polyethylene vials and heat sealed for neutron activation analysis (NAA).

The standard sequential INAA procedure (Laul, 1979) was used, employing the 1 MW TRIGA research reactor at the Radiation Center of Oregon State University. We used CRB (an in- house powder equivalent to BCR-1, both taken from the same basalt quarry) and NBS-1633a as standards in the NAA procedure. A Ge(Li) detector coupled to a multichannel analyzer was used. A 5-mm-thick HPGe detector was used for obtaining more accurate ${ }^{141} \mathrm{Ce}(145.4 \mathrm{keV} \gamma)$ and ${ }^{147} \mathrm{Nd}(91.1 \mathrm{keV} \gamma)$ data to determine the $\mathrm{Ce}^{\mathrm{A}}$ values. All data were computer reduced.

\section{DISCUSSION}

In Table 1, we note that a disproportionate number of carbonates from Holes 706A to 711A on and near the Mascarene Plateau and Madingley Rise (14) were requested and analyzed relative to carbonates from Holes $712 \mathrm{~A}, 713 \mathrm{~A}$, and $716 \mathrm{~A}$ on or near the Chagos Bank-Maldives Ridge (4). The overall chemical composition of these relatively pure carbonates are similar to those from the western, central, and eastern Pacific Ocean. In Figure 1, we have plotted the REE + Sc as a group and the minor and trace elements $\mathrm{Co}$-Ta in their decreasing hydroxide solubility products (e.g., $\mathrm{K}_{\mathrm{sp}} \mathrm{Co}(\mathrm{OH})_{2}, \sim 10^{-15} ; \mathrm{Fe}(\mathrm{OH})_{3}, \sim 10^{-39}$; and $\left.\mathrm{Ti}(\mathrm{OH})_{4}, \sim 10^{-58}\right)$. As pointed out by Jin and Schmitt (1989a), the fairly constant ratios of trace elements like $\mathrm{Cr}, \mathrm{Al}$, $\mathrm{V}, \mathrm{Fe}, \mathrm{Th}, \mathrm{Hf}$, and $\mathrm{Ti}$ strongly indicate that these elements are contained in detrital clay particles rather that controlled by diagenetic hydrogenous reactions such as coprecipitation of insoluble oxyhydroxides.

In four Indian Ocean < 1-46-Ma carbonates (Fig. 1A), only $1 \%-2 \%$ of detrital clay component is evident. Similar detrital clay components of $\sim 0.6 \%-2 \%$ were reported (Liu et al., 1988; Jin and Schmitt, 1989a) in Pacific carbonates (Figs. 1B and 1C). For both Indian and Pacific carbonates, anomalously high Mn abundances are observed and are attributed to the diagenetic growth of insoluble $\mathrm{Mn}^{+3}$ and $\mathrm{Mn}^{+4}$ oxyhydroxides that coat the sedimentary carbonates (Palmer, 1985) during their $\sim 10^{5}-$ $10^{7}$-yr exposure to interstitial seawater. Manganese is appreciably reduced only in pristine carbonates in Hole 577, Cretaceous/ Tertiary boundary samples (Jin and Schmitt, 1989b).

For Sample 115-706A-1H-2 (Fig. 1A), the very low normalized ratio of $\mathrm{Al}$ suggests a detrital clay component of $0.15 \%$ and possibly hydrogenous components for $\mathrm{Cr}, \mathrm{Fe}$, Th, and $\mathrm{Hf}$. Despite the relatively higher $\mathrm{K}_{\mathrm{sp}}$ for $\mathrm{Co}(\mathrm{OH})_{2}$, we attribute the relatively high normalized and similar Co contents in the Indian and Pacific ocean carbonates to diagenetic hydrogenous growth of $\mathrm{Co}^{+2}$ oxyhydroxides in the $\mathrm{Fe}-\mathrm{Mn}$ - $\mathrm{Al}$-Ti-oxyhydroxide coatings, similar to the $\mathrm{Mn}$ and Co enrichments exhibited in $\mathrm{Mn}$ nodules (e.g., Dymond et al., 1984). Thermochemical calculations rule out the oxidation of $\mathrm{Co}^{+2}$ to $\mathrm{Co}^{+3}$ via $\mathrm{Co}^{+2}+3 \mathrm{OH}^{-}$ $\rightarrow \mathrm{Co}(\mathrm{OH})_{3}+\mathrm{e}^{-}$as a possible diagenetic reaction.

We note the relatively higher normalized REE contents in the Indian Ocean carbonates (except Sample 115-706A-1H-2) relative to the detrital clay component by $\sim 10-30 \times$ and by factors of $30-100 \times$ in other Pacific carbonates. The comparable REE contents (Ce excepted) of $\sim 0.3 \times$ NASC in these bulk carbonates are attributed to diagenetic growth (Liu et al., 1988) of $\mathrm{REEPO}_{4}$ in the Fe-Mn-Al-Ti-oxyhydroxide coatings of sedimentary carbonate minerals.

Europium exhibits a small positive anomaly in western and eastern Pacific carbonates relative to the Indian Ocean and Central Pacific carbonates. Perhaps the lower ratio of HREE (Tb$\mathrm{Lu})$ /LREE ( $\mathrm{La}-\mathrm{Sm})$ in the former carbonates may be responsible for an apparent Eu anomaly in the former carbonates.

Detrital-clay-particulate corrected $\mathrm{Ce}^{\mathrm{A}} \mathrm{s}$ in 18 Indian carbonates range from $0.07 \pm 0.01$ (Sample $115-711 \mathrm{~A}-16 \mathrm{X}-5$ ) to 0.48 \pm 0.02 (Sample 115-707A-1H-2) in samples from the Mascarene Plateau and Madingley Rise and $0.12 \pm 0.01$ (Sample 115$712 \mathrm{~A}-12 \mathrm{H}-2$ ) to $0.66 \pm 0.02$ (Sample $115-716 \mathrm{~A}-24 \mathrm{H}-4$ ) in samples from the Chagos Bank-Maldives Ridge. For plotting reliable $\mathrm{Ce}^{\mathrm{A}^{*}}$ values, we have adopted the following criteria: low detrital clay content of $\mathrm{Al}<0.20 \%$ equivalent to $2 \%$ NASC- 
Table 1. Elemental abundances in marine carbonates from Holes 706A, 707A, 708A, 709C, 710A, 711A, 712A, 713A, and 716A.

\begin{tabular}{|c|c|c|c|c|c|c|c|c|c|c|c|c|c|c|c|c|c|c|c|}
\hline Site, hole & $706 \mathrm{~A}$ & $706 \mathrm{~A}$ & $707 \mathrm{~A}$ & $707 \mathrm{~A}$ & $707 \mathrm{~A}$ & $708 \mathrm{~A}$ & $708 \mathrm{~A}$ & $709 \mathrm{C}$ & $709 \mathrm{C}$ & $709 \mathrm{C}$ & $710 \mathrm{~A}$ & $710 \mathrm{~A}$ & $711 \mathrm{~A}$ & $711 \mathrm{~A}$ & $712 \mathrm{~A}$ & $712 \mathrm{~A}$ & $713 \mathrm{~A}$ & $716 \mathrm{~A}$ & \\
\hline Core, section & IH-2 & $5 \mathrm{H}-3$ & $1 \mathrm{H}-2$ & $16 \mathrm{H}-1$ & $22 \mathrm{X}-5$ & $1 \mathrm{H}-2$ & $21 \mathrm{X}-2$ & $21 X-4$ & $26 \mathrm{X}-6$ & $35 \mathrm{X}-2$ & $2 \mathrm{H}-2$ & $21 \times-5$ & $10 \mathrm{H}-2$ & $16 \mathrm{X}-5$ & $11 \mathrm{H}-1$ & $12 \mathrm{H}-2$ & $2 \mathrm{R}-5$ & $24 \mathrm{H}-4$ & \\
\hline Interval $(\mathrm{cm})$ & $51-52$ & $10-11$ & $53-54$ & $54-55$ & $134-135$ & $70-71$ & $53-54$ & $30-31$ & $14-15$ & $60-61$ & $14-15$ & $132-133$ & $132-133$ & 44-45 & $60-61$ & $90-91$ & $103-104$ & 96-97 & \\
\hline Ocean depth (m) & 2508 & 2508 & 1541 & 1541 & 1541 & 4097 & 4097 & 3038 & 3038 & 3038 & 3812 & 3812 & 4428 & 4428 & 2892 & 2892 & 2910 & 533 & \\
\hline Depth (mbsf) & 2 & 35 & 2 & 142 & 200 & 2 & 190 & 194 & 245 & 326 & 11 & 198 & 88 & 150 & 97 & 108 & 9 & 2 & aErrors \\
\hline Age (Ma) & $<1$ & 33 & $<1$ & 23 & 38 & $<1$ & 26 & 23 & 33 & 46 & 1.0 & 32 & 26 & 36 & 30 & 31 & 3 & 8 & $(\%)$ \\
\hline \multicolumn{20}{|c|}{ Major and minor elements: } \\
\hline Ti $(\%)$ & - & 0.12 & 0.015 & 0.011 & - & 0.011 & 0.026 & 0.010 & - & 0.017 & - & - & 0.011 & 0.016 & 0.010 & 0.077 & 0.019 & 0.037 & $15-30$ \\
\hline Al & 0.012 & 0.54 & 0.041 & 0.081 & 0.074 & 0.055 & 0.41 & 0.24 & 0.115 & 0.086 & 0.29 & 0.18 & 0.42 & 0.20 & 0.009 & 0.51 & 0.22 & 0.28 & $2-30$ \\
\hline $\mathrm{Fe}$ & 0.066 & 0.72 & 0.021 & 0.064 & 0.037 & 0.052 & 0.215 & 0.254 & 0.137 & 0.097 & 0.212 & 0.184 & 0.44 & 0.189 & 0.049 & 0.47 & 0.175 & 0.159 & $2-5$ \\
\hline $\mathrm{Mg}$ & 0.67 & 0.53 & 0.63 & 0.34 & 0.34 & 0.77 & 0.53 & 0.32 & 0.24 & 0.19 & 0.24 & 0.37 & 0.29 & 0.34 & 0.67 & 0.40 & 0.50 & 0.27 & $10-30$ \\
\hline $\mathrm{Ca}$ & 37.3 & 33.1 & 38.4 & 37.6 & 36.3 & 36.7 & 36.0 & 36.4 & 36.6 & 35.6 & 35.8 & 36.2 & 35.2 & 37.0 & 38.1 & 35.0 & 36.1 & 37.6 & 3 \\
\hline $\mathrm{Na}$ & 1.07 & 0.69 & 2.74 & 0.81 & 0.51 & 0.56 & 0.66 & 0.78 & 0.82 & 0.54 & 0.75 & 0.78 & 0.850 & 0.53 & 0.48 & 0.48 & 0.92 & 0.63 & 2 \\
\hline$K(\%)$ & 0.049 & 0.25 & 0.091 & 0.024 & 0.030 & 0.043 & 0.18 & 0.057 & 0.041 & 0.035 & 0.13 & 0.021 & 0.022 & 0.035 & 0.016 & 0.24 & 0.082 & 0.049 & $15-50$ \\
\hline \multicolumn{20}{|c|}{ Minor and trace elements: } \\
\hline $\mathrm{Sc}(\mathrm{ppm})$ & 0.32 & 2.28 & 0.53 & 0.86 & 0.60 & 0.34 & 1.10 & 0.99 & 0.59 & 0.74 & 1.25 & 0.73 & 1.57 & 0.95 & 0.070 & 2.61 & 1.25 & 0.89 & 2 \\
\hline $\mathrm{v}$ & 1.9 & 21 & 2.7 & 2.6 & - & 4.0 & 5.8 & 3.5 & - & 1.2 & 9.9 & 4.3 & 8.6 & 3.3 & 3.7 & 6.3 & 4.9 & 15.3 & $8-40$ \\
\hline $\mathrm{Cr}$ & 0.75 & 9.8 & 0.92 & 1.0 & 0.71 & 4.7 & 6.8 & 2.5 & 1.3 & 1.3 & 4.6 & 1.6 & 4.3 & 2.4 & 8.5 & 2.0 & 2.8 & 14.3 & $2-10$ \\
\hline $\mathrm{Mn}$ & 53 & 1080 & 33 & 118 & 189 & 124 & 280 & 279 & 191 & 146 & 252 & 198 & 482 & 287 & 59 & 236 & 159 & 20 & 2 \\
\hline Co & 2.6 & 1.3 & 0.37 & 2.2 & 0.57 & 0.85 & 0.85 & 2.4 & 0.67 & 0.47 & 2.2 & 0.76 & 2.9 & 0.46 & 0.26 & 1.5 & 1.8 & 1.4 & $2-3$ \\
\hline $\mathrm{Ni}$ & 3.2 & 6 & - & 4.5 & 3.8 & 4.3 & 10 & 10 & 4.6 & 4.4 & 9 & 7 & 13 & 6 & 1.8 & 4 & 10 & 19 & $5-25$ \\
\hline $\mathrm{Zn}$ & 12 & 18 & 8 & 11 & 9 & 5 & 8 & 14 & 8 & 8 & 10 & 6 & 16 & 10 & 20 & 12 & 9 & 17 & $3-15$ \\
\hline $\mathrm{Rb}$ & 0.4 & 7.5 & 0.2 & 1.2 & 0.2 & 0.4 & 2.5 & 2.2 & 0.9 & 0.9 & 3.8 & 1.9 & 4.0 & 1.4 & 0.16 & 2.7 & 2.6 & 3.6 & $10-50$ \\
\hline Sr & 1050 & 870 & 1070 & 910 & 470 & 2200 & 1190 & 1230 & 1390 & 590 & 1270 & 1610 & 1770 & 1490 & 370 & 720 & 1090 & 1780 & $3-6$ \\
\hline $\mathrm{Sb}$ & 0.025 & 0.23 & 0.12 & 0.06 & 0.014 & 0.026 & 0.07 & 0.031 & 0.015 & 0.11 & 0.15 & 0.05 & 0.14 & 0.5 & 0.27 & 0.17 & 0.13 & 0.23 & $10-30$ \\
\hline Cs & 0.025 & 0.26 & 0.04 & 0.026 & 0.024 & 0.033 & 0.12 & 0.08 & 0.05 & 0.023 & 0.21 & 0.06 & 0.13 & 0.05 & - & 0.10 & 0.15 & 0.22 & $5-40$ \\
\hline $\mathrm{Ba}$ & 20 & 125 & 99 & 310 & 370 & 120 & 500 & 750 & 850 & 760 & 720 & 750 & 650 & 900 & 13 & 470 & 640 & 48 & $3-7$ \\
\hline $\mathrm{La}$ & 2.36 & 5.4 & 2.18 & 7.2 & 5.6 & 1.58 & 15.0 & 7.4 & 5.0 & 5.5 & 5.4 & 5.9 & 11.6 & 7.7 & 0.85 & 5.4 & 6.5 & 3.7 & 2 \\
\hline $\mathrm{Ce}$ & 1.28 & 6 & 2.29 & 3.7 & 1.67 & 1.71 & 11.8 & 5. & 2. & 2 & 4. & 3.3 & 8.1 & 2.5 & 0.51 & 4.4 & 5.1 & 6.2 & 3-8 \\
\hline $\mathrm{Nd}$ & 2.0 & 4.3 & 2.1 & 6.2 & 4.3 & 1.72 & 13.4 & 6.9 & 5.4 & 6.5 & 6.0 & 7.1 & 14.2 & 9.5 & 0.63 & 6.1 & 7.5 & 4.8 & $3-16$ \\
\hline $\mathrm{Sm}$ & 0.44 & 0.98 & 0.44 & 1.16 & 0.86 & 0.43 & 2.85 & 1.35 & 0.91 & 0.84 & 0.95 & 1.05 & 2.18 & 1.45 & 0.167 & 0.90 & 1.26 & 1.10 & 2 \\
\hline $\mathrm{Eu}$ & 0.109 & 0.27 & 0.118 & 0. & 0.201 & 0.066 & 0.66 & 0.3 & 0.224 & 0.234 & 0.2 & 0.2 & 0.60 & 0.3 & 0.027 & 0.28 & 0.33 & 0.157 & $2-8$ \\
\hline $\mathrm{Tb}$ & 0.079 & 0. & 0.086 & 0.20 & 0.14 & 0.044 & 0.48 & 0.2 & 0.15 & 0.17 & $0 . c$ & 0.1 & 0.40 & 0.2 & 0.027 & 0.21 & 0.23 & 0.11 & $4-12$ \\
\hline Dy & 0.65 & 1.19 & 0.99 & 1.58 & 0.95 & 0.41 & 2.82 & 1.36 & 0.97 & 1.1 & 1.1 & 0. & 2.43 & 1.58 & 0.29 & 1.23 & 1.59 & 0.67 & $7-25$ \\
\hline $\mathrm{Yb}$ & 0.28 & 0.55 & 0.36 & 0.82 & 0.52 & 0.151 & 1.48 & 0.80 & 0.48 & 0.46 & 0.62 & 0.55 & 1.15 & 0.71 & 0.070 & 0.62 & 0.87 & 0.35 & $2-10$ \\
\hline Lu & 0.039 & 0.073 & 0.050 & 0.108 & 0.066 & 0.038 & 0.186 & 0.107 & 0.062 & 0.062 & 0.090 & 0.070 & 0.15 & 0.090 & 0.015 & 0.085 & 0.120 & 0.09 & $3-30$ \\
\hline $\mathrm{Hf}$ & 0.020 & 0.36 & 0.036 & 0.13 & 0.022 & 0.031 & 0.50 & 0.18 & 0.08 & 0.05 & 0.17 & 0.08 & 0.36 & 0.07 & - & 0.20 & 0.13 & 0.11 & $4-20$ \\
\hline $\mathrm{Ta}$ & - & 0.10 & _- & 0.043 & 0.006 & 0.005 & 0.080 & 0.040 & 0.019 & 0.009 & 0.040 & 0.017 & 0.12 & 0.018 & - & 0.036 & 0.036 & 0.028 & $10-40$ \\
\hline Th & 0.091 & 0.23 & 0.17 & 0.20 & 0.073 & 0.070 & 0.76 & 0.39 & 0.16 & 0.14 & 0.46 & 0.24 & 0.69 & 0.28 & - & 0.15 & 0.45 & 0.38 & $2-7$ \\
\hline U & 0.15 & 0.32 & 0.11 & 0.11 & 0.048 & 1.83 & 0.43 & 0.12 & 0.097 & 0.086 & 0.15 & 0.13 & 0.18 & 0.069 & 0.70 & 0.098 & 0.19 & 5.4 & $2-20$ \\
\hline${ }^{b} \mathrm{Ce}^{\mathrm{A}^{\mathbf{A}^{*}}}$ & 0.26 & 0.36 & 0.48 & 0.23 & $\begin{array}{l}0.048 \\
0.11\end{array}$ & 0.44 & $\begin{array}{l}0.43 \\
0.33\end{array}$ & 0.29 & 0.17 & $\begin{array}{l}0.150 \\
0.15\end{array}$ & 0.25 & 0.18 & 0.23 & $\begin{array}{l}0.069 \\
0.07\end{array}$ & 0.29 & $\begin{array}{l}0.098 \\
0.12\end{array}$ & $\begin{array}{l}0.19 \\
0.28\end{array}$ & 0.66 & $2-20$ \\
\hline
\end{tabular}

Estimated error ranges; low errors correspond to high concentration values and high errors to low concentration values. lates. 


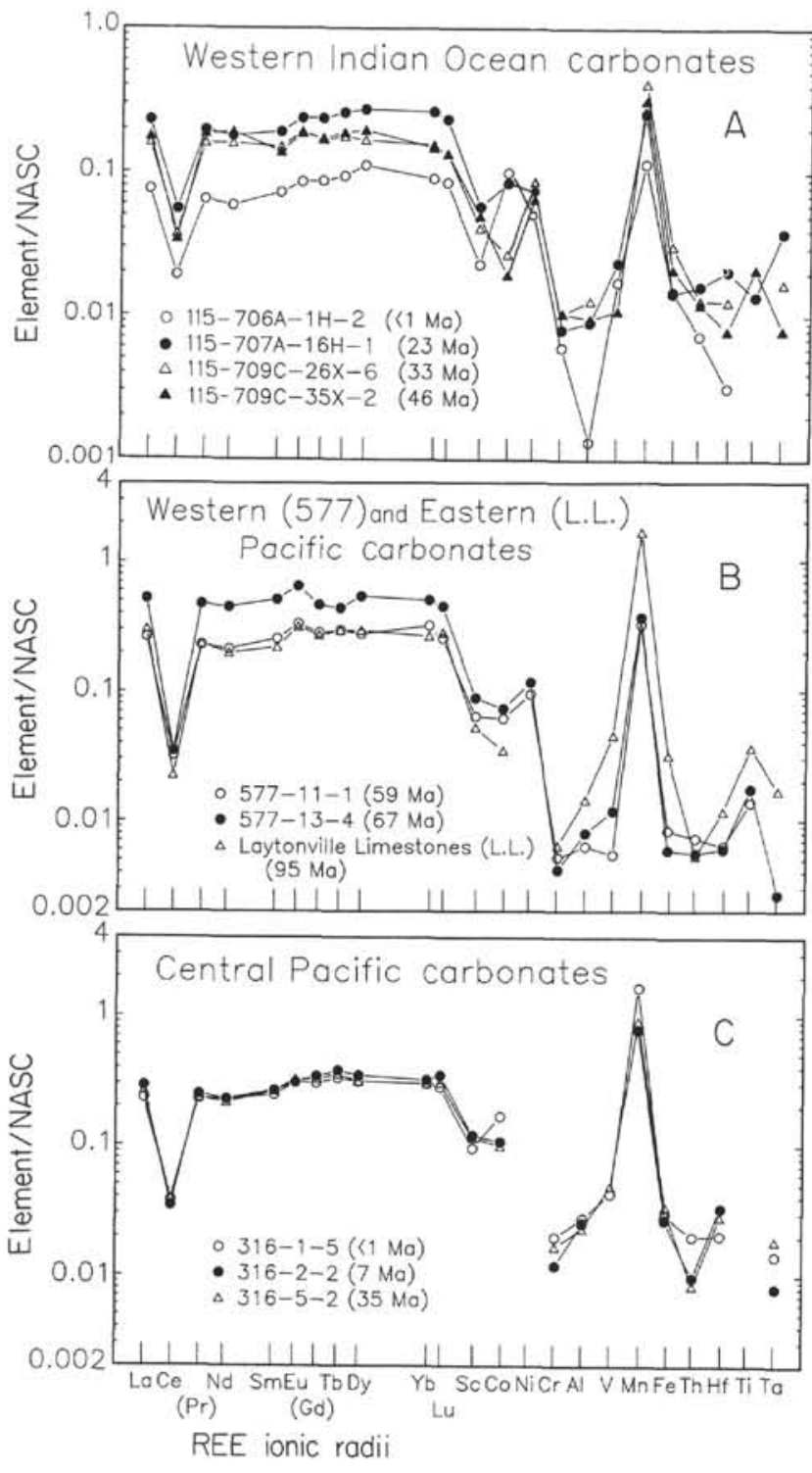

Figure 1. Element abundances, normalized to $\mathrm{La}=31 \mathrm{ppm}, \mathrm{Ce}=67$ $\mathrm{ppm}$, and $\mathrm{Nd}=\mathrm{ppm}$ in North American Shale Composite (NASC) (Gromet et al., 1984), in the western Indian Ocean and in western, central, and eastern Pacific Ocean carbonates. The sequence of elements from Co-Ta reflect decreasing $\mathrm{K}_{\mathrm{sp}} \mathrm{s}$ of their insoluble hydroxide compounds. $\mathrm{Pr}$ and $\mathrm{Gd}$ are interpolated abundances.

like clay, a low $U$ abundance of $<0.15 \mathrm{ppm}$ (Liu et al., 1988), and a $\mathrm{Mn} / \mathrm{Al}$ ratio of $>1000$ (Jin and Schmitt, 1989b). The latter two criteria are strong indicators for oceanic oxic conditions. Reducing or anoxic conditions could restrict the degree of oxidation of $\mathrm{Ce}^{+3}$ to $\mathrm{Ce}(\mathrm{OH})_{4}$, resulting in higher $\mathrm{Ce}^{\mathrm{A}}$ values.

Seven bulk carbonate specimens from the Mascarene Plateau and Madingley Rise area fall within these three criteria (i.e., Samples 115-706-1H-2, 115-707A-16H-1, 115-707A-22X-5, 115-709C$26 \mathrm{X}-6,115-709 \mathrm{C}-35 \mathrm{X}-2,115-710 \mathrm{~A}-21 \mathrm{X}-5$, and 115-711A-16X-5. As shown in Figure 2, these seven $\mathrm{Ce}^{\mathrm{A}^{*}}$ values $( \pm 1 \sigma)$ average $0.17 \pm 0.07$ over a $46-\mathrm{Ma}$ interval. We note in Figure 2 that five of these seven carbonates fall between 32 and $46 \mathrm{Ma}$ and yield an average $\mathrm{Ce}^{\mathrm{A}^{*}}$ of $0.14 \pm 0.05$. Following the Liu et al. (1988) discussion of $\mathrm{Ce}$ anomalies in pure marine carbonates and their equivalence to cognate seawater, we note that the $\mathrm{Ce}^{\mathrm{A}}$ in the Indian Ocean was $0.14 \pm 0.05$ over the interval from 32 to $46 \mathrm{Ma}$,

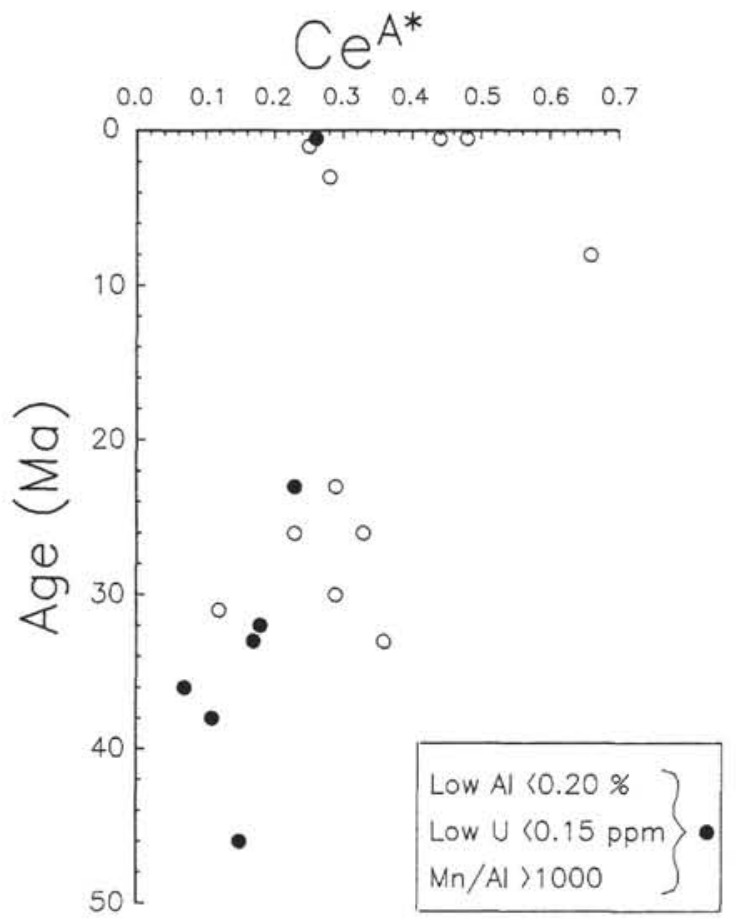

Figure 2. $\mathrm{Ce}^{\mathrm{A}^{*}}$ s are Ce anomalies ( $\equiv \mathrm{Ce}$ observed/Ce interpolated between $\mathrm{La}$ and $\mathrm{Nd}$ ) in the western Indian Ocean carbonates, corrected for REE in NASC-like clay particulates in carbonates by assuming the fraction of clay in carbonates equals $\mathrm{Al}$ (carbonates)/ $\mathrm{Al}$ (9.9\% in NASC). Solid circles $=$ carbonates formed in normal oxic oceanic conditions as defined by criteria in the box; open circles = carbonates formed in more reducing oceanic conditions as evidenced by lower $\mathrm{Mn} / \mathrm{Al}$ and higher $\mathrm{U}$ abundances.

which compares with $\mathrm{Ce}^{\mathrm{A}}$ values in the eastern Pacific Ocean at $95 \mathrm{Ma}$ of $0.034 \pm 0.018$ (LL data noted in the "Introduction"), $0.08 \pm 0.04$ in the central Pacific Ocean from $<1-75-\mathrm{Ma}$ Hole 316 carbonate data, and 0.05 in the western Pacific Ocean at the 66-67-Ma period (Cretaceous/Tertiary boundary phenomena excluded; Goles and Schmitt, 1989).

Assuming the western Indian Ocean value of 0.14 and the median Pacific Ocean value of 0.05 , we calculate an expected lower average $\mathrm{pH}$ of 0.16 in the Indian Ocean by using the Liu et al. (1988) Ce redox formulation, which indicates a strong $\mathrm{pH}$ dependency on the log $[\mathrm{Ce}]$ in seawater. (Because of different diagenetic growth rates for $\mathrm{REEPO}_{4}$ in the Fe-Mn-Al-Ti-oxyhydroxide coatings of carbonate minerals, absolute and corrected Ce concentrations in marine carbonates are not used in the calculations, but the changes in relative $\mathrm{Ce}^{\mathrm{A}}$ values of the different oceans are used.) This calculated difference of 0.16 agrees well with a difference of 0.15 between the average pHs of 8.12 in the upper $200 \mathrm{~m}$ of the western Indian Ocean (Stations 418 and 421; GEOSECS Atlas, 1983) and the average pHs of 8.27 in the upper $200 \mathrm{~m}$ of the western and eastern Pacific Ocean (Stations 230 and 326; GEOSECS Atlas, 1982).

The remarkable agreement between predicted and observed $\mathrm{Ce}^{\mathrm{A}}$ values in the western Indian and Pacific oceans suggests verification of the Liu et al. (1988) theory for $\mathrm{Ce}^{+3}$ oxidation to insoluble $\mathrm{Ce}(\mathrm{OH})_{4}$ within the oceanic mixed layer. Because the average $\mathrm{pH}$ is 8.25 in the South Atlantic $200-\mathrm{m}$ layer south of the Walvis Ridge at Station 103 (GEOSECS Atlas, 1981), the $\mathrm{Ce}^{\mathrm{A}}$ of the South Atlantic Ocean should be comparable to the $\mathrm{Ce}^{\mathrm{A}}$ of the Pacific Ocean. However, from the Liu and Schmitt (1984) data, we calculate an average $\mathrm{Ce}^{\mathrm{A}^{*}}=0.28 \pm 0.04$ for ten $\sim 1-58-\mathrm{Ma}$ bulk carbonates with $\mathrm{Al}$ contents and $\mathrm{Mn} / \mathrm{Al}$ ratios 
ranging from $0.11 \%$ to $0.25 \%$ and from 550 to 2050 , respectively. For three of those ten carbonates with $\mathrm{Al}$ and $\mathrm{Mn} / \mathrm{Al}$ $<0.18 \%$ and $>990$, respectively, the average $\mathrm{Ce}^{\mathrm{A}^{*}}$ equals 0.27 \pm 0.05 , which overlaps the $\mathrm{Ce}^{\mathrm{A}}$ of $0.18 \pm 0.12$ in Atlantic seawater (Høgdahl et al., 1968). Uranium abundances were determined in only two of the ten carbonates at 0.17 and $0.044 \mathrm{ppm}$.

The higher $\mathrm{Ce}^{\mathrm{A}^{*}}$ values in South Atlantic carbonates by $\sim 4 \times$ relative to Pacific carbonates, both deposited under apparently similar oxic conditions and containing low detrital clay particulates, simply reflect $\mathrm{La}+\mathrm{Nd}$ and $\mathrm{Ce}$ abundances in Atlantic carbonates that are $\sim 0.5 \times$ and $\sim 2.0 \times$ those observed in Pacific carbonates, respectively. We interpret the higher $\mathrm{Ce}^{\mathrm{A}}$ in the Atlantic Ocean in terms of curtailed inhibition of $\mathrm{Ce}^{+3}$ oxidation of $\mathrm{Ce}(\mathrm{OH})_{4}$. The discharge into the Atlantic Ocean is dominated by $\sim 75 \%$ of river water originating in warm, humid, and tropical regions of South America and Africa, resulting in the transport of an enhanced load of decayed organic debris and soluble organic compounds for sustaining a reducing environment. The presence of more abundant organic molecules is expected to complex seawater cations including the $\mathrm{REE}^{+3}$, thereby reducing the degree of $\mathrm{Ce}^{+3}$ oxidation. The smaller fraction of tropical river water discharges into the Pacific ocean could account for the dominance of $\mathrm{CePO}_{4}^{0}$ as the primary complex ion in the $\mathrm{Ce}^{+3}$ oxidation mechanism (Liu et al., 1988).

Liu et al. (1988) suggested that marine carbonates with low $\mathrm{U}$ are reliable indicators of paleoredox $\left(\mathrm{P}_{\mathrm{CO}_{2}}-\mathrm{pH}\right)$ conditions in ancient oceans because of the reduction of a small fraction of the abundant $\mathrm{UO}_{2}^{++}\left(\mathrm{U} / \mathrm{Th} \sim 3 \times 10^{4}\right.$ in seawater $)$ to $\mathrm{U}^{+4}$, which will readily precipitate because of its very low hydroxide $\mathrm{K}_{\mathrm{sp}}$ of $\sim 10^{-55}$. Very high $\mathrm{U}$ contents of $0.32-5.4 \mathrm{ppm}$ were measured in five samples: $115-706 \mathrm{~A}-5 \mathrm{H}-3,115-708 \mathrm{~A}-1 \mathrm{H}-2,115-$ $708 \mathrm{~A}-21 \mathrm{X}-2,115-712 \mathrm{~A}-11 \mathrm{H}-1$, and $115-716 \mathrm{~A}-24 \mathrm{H}-4$ with no correlations to ages of deposition that range from $<1$ to $\sim 33 \mathrm{Ma}$. The $\mathrm{Ce}^{\mathrm{A}^{*}}$ in these five carbonates ranged from 0.29 to 0.66 , which are considerably higher than the average $\mathrm{Ce}^{\mathrm{A}^{*}}$ observed in the five pristine carbonates (Fig. 2) from 32 to $46 \mathrm{Ma}$. These higher $\mathrm{Ce}^{\mathrm{A}^{*}} \mathrm{~s}$ are consistent with the Liu et al. (1988) suggestion that anoxic conditions will reduce some $\mathrm{UO}_{2}^{++}$in seawater both above the seawater-sediment interface and in the sedimentary pore waters and simultaneously reduce $\mathrm{Ce}(\mathrm{OH})_{4}$ to the more soluble $\mathrm{Ce}(\mathrm{OH})_{3}^{0}$. Formation of the latter will enhance the $\mathrm{Ce}^{\mathrm{A}}$ value in the carbonate sediments.

It was noted previously that a disproportionate number (4) of carbonates from the Chagos Bank-Maldives Ridge were studied relative to 14 carbonates from the Mascarene Plateau-Madingley Rise. Judging from the high $\mathrm{U}$ contents in two carbonates (Samples 115-712A-11H-1 and 115-716A-24H-4) from the later general area and three (Samples 115-706A-5H-3, 115-708A-1H-2, and 115-708A-21X-2) from the former, it seems that strong anoxic conditions occurred randomly through the $<1-33-\mathrm{Ma}$ interval of these five samples, thereby suggesting mixing throughout the western Indian Ocean.

In Figure 2, we note that all of the $\mathrm{Ce}^{\mathrm{A}^{*}}$ values from $<1$ to $30 \mathrm{Ma}$ are $>0.23$ with an average of $0.34 \pm 0.13$. Only two of these samples are included among the samples (solid circles) that have been characterized as "oxic deposited" marine carbonates. The significantly higher average $\mathrm{Ce}^{\mathrm{A}^{*}}$ of $0.34 \pm 0.13$ for the 11 younger carbonates compared with $0.14 \pm 0.05$ for the five 32-46-Ma carbonates indicates more reducing conditions in the western Indian ocean during the $<1-30$-Ma interval and normal oxic conditions during the period from 32 to $46 \mathrm{Ma}$. It has been recently reported (Leg 116 Shipboard Scientific Party, 1987) that the presence of large volumes of terrigenous sediment in the eastern Indian ocean via the Bengal Fan in the early Miocene implied the existence of a voluminous sediment source, presumably from the pronounced relief of the Himalayas in the India-Asia collision zone at least during the past $24 \mathrm{Ma}$.
In addition to larger volumes of terrigenous sediments, a larger amount of decayed organic debris and soluble organic components are expected from the weathering of the Himalayan rise. Following the interpretation for the higher observed $\mathrm{Ce}^{\mathrm{A}} \mathrm{s}$ in the Atlantic Ocean and in marine carbonates, we suggest that the inferred higher $\mathrm{Ce}^{\mathrm{A}}$ of the Indian Ocean during the past $30 \mathrm{Ma}$ is attributed to generally more anoxic conditions throughout the ocean with a direct effect on Ce redox conditions. Consistent with the Leg 116 Shipboard Scientific Party (1987) and the Sadasivan et al. (1981) observations and our $\mathrm{Ce}^{\mathrm{A}}$ data, we suggest that the Himalayan relief was sufficiently prominent at $32 \pm 1 \mathrm{Ma}$ for weathering and transport phenomena similar to the present regime. In fact, the Ce data suggest that prominent relief may have been achieved over only a few Ma interval, say from 33-30 Ma. Perhaps the Himalayan Rise began 33-35 Ma.

The above interpretation may be compared to the suggestion by the Leg 116 Shipboard Scientific Party (1987), namely, that the major uplift of the Himalayas had begun by the early Miocene. Sadasivan et al. (1981), studying sediments of the Arabian Sea, also suggested a major tectonic episode at about this time. We also agree with some reviewers that the link between $\mathrm{Ce}^{\mathrm{A}^{*}} \mathrm{~s}$ and the accelerated rise of the Himalayan uplift may be somewhat tenuous, particularly since such a small, high relief drainage basin and monsoonal rainfall possibly may not have produced enhanced transport of organic debris into the Indian Ocean. Perhaps other phenomena such as ocean circulation changes or monsoonal upwelling variabilities may be invoked for the $\mathrm{Ce}^{\mathrm{A}}$ changes that seem to have begun at $\sim 33 \mathrm{Ma}$.

\section{CONCLUSIONS}

Patterns of the minor and trace elements REE, Sc, Co, Ni, $\mathrm{Al}, \mathrm{V}, \mathrm{Mn}, \mathrm{Fe}, \mathrm{Th}, \mathrm{Hf}, \mathrm{Ti}$, and $\mathrm{Ta}$, normalized to NASC, are similar in western Indian Ocean bulk carbonates to western, central, and eastern Pacific carbonates. Normalized REE abundances are $\sim 10 \times$ higher in these carbonates relative to trace elements with decreasing hydroxide solubilities $(\mathrm{Cr}-\mathrm{Ta})$, suggesting diagenetic $\mathrm{REEPO}_{4}$ precipitation in the Fe-Mn-Al-Ti-oxyhydroxide coating of the carbonate minerals during the $\sim 10^{5}-10^{7}$ yr exposure to seawater.

Normalized Mn exhibits a pronounced enrichment attributed to precipitation of $\mathrm{Mn}^{+3}$ and $\mathrm{Mn}^{+4}$ compounds in the FeMn-Al-Ti-oxyhydroxide coatings of carbonate minerals. An average $\mathrm{Ce}^{\mathrm{A}^{*}}=0.14 \pm 0.05$ was found in five Mascarene Plateau-Madingley Rise carbonates of 32-46 Ma age. This average $\mathrm{Ce}$ anomaly is considered to represent normal oxic conditions in the western Indian Ocean during the 32-46-Ma interval.

Consistent with the observations of the Leg 116 Shipboard Scientific Party (1987), we think that the Himalayan relief was sufficiently prominent at $32 \pm 1 \mathrm{Ma}$ for enhanced weathering and water transport conditions that are similar to the present regime. From the $\mathrm{Ce}^{\mathrm{A}}$ data, we propose that the Himalayan Mountains began an accelerated rise at $\sim 33-35 \mathrm{Ma}$.

\section{ACKNOWLEDGMENTS}

This work was supported by the Radiation Center and in part by NASA grant NAG 9-63. We are grateful to S. S. Hughes for discussions and to the reviewers of this manuscript: E. J. Dasch, R. B. Dunbar, and A. V. Murali. We also acknowledge the assistance of the OSU TRIGA reactor crew for the neutron activations.

\section{REFERENCES}

DeBaar, H.J.W., Bacon, M. P., Brewer, P. G., and Bruland, K. W., 1985. Rare earth elements in the Pacific and Atlantic oceans. Geochim. Cosmochim. Acta, 49:1943-1959.

Dymond, J., Lyle, M., Finney, B., Piper, D. Z., Murphy, K., Conard, R., and Pisias, N., 1984. Ferromanganese nodules from MANOP 
Sites H, S, and R-control of mineralogical and chemical composition by multiple accretionary processes. Geochim. Cosmochim. Acta, 48:931-950.

Ehrlich, A. M., 1968. Rare earth abundances in manganese nodules [Ph.D. thesis]. M.I.T., Cambridge, MA.

GEOSECS Atlas, 1981. Atlantic Expedition (Vol. 1), Hydrographic Data (1972-1973). 1974).

1982. Pacific Expedition (Vol. 3), Hydrographic Data (1972-

1983. Indian Ocean Expedition (Vol. 5), Hydrographic Data (1977-1978).

Goldberg, E. D., 1961. Chemistry in the oceans. Oceanography, 582597.

Goldberg, E. D., Koide, M., Schmitt, R. A., and Smith, R. H., 1963. Rare earth distribution in the marine environment. J. Geophys. Res., 68:4209-4217.

Goles, G. G., and Schmitt, R. A., 1989. Pristine Shatsky Rise K/T marine carbonates yield negative $\mathrm{Ce}$ anomalies slightly higher than present Pacific Ocean, implying a slightly lower $\mathrm{pH}$ of 8.0; IV. Lunar Planet. Sci., 20:343-344.

Gromet, L. P., Dymek, R. F., Haskin, L. A., and Korotev, R. L., 1984. The "North American Shale Composite": its compilation, major and trace element characteristics. Geochim. Cosmochim. Acta, 48: 2469-2482.

Høgdahl, O. T., Melson, S., and Bowen, V. T., 1968. Neutron activation analysis of lanthanide elements in sea water. Adv. Chem. Ser., 33:308-325.

Hu, S., Wang, Y. L., and Schmitt, R. A., 1988. Geochemistry of sediments on the Rio Grande Rise and the redox evolution of the South Atlantic Ocean. Geochim. Cosmochim. Acta, 52:201-207.

Jin, G.-Y., and Schmitt, R. A., 1989a. Pristine Shatsky Rise K/T marine carbonates yield $\mathrm{Fe}_{\mathrm{NET}} / \mathrm{Ir}_{\mathrm{NET}}=\mathrm{Cl}$ chondritic ratio: no evi- dence for Fe from terrestrial crater ejecta rules out direct asteroidcomet impact. I. Observations. Lunar Planet. Sci., 20:460-461.

, 1989b. Pristine Shatsky Rise K/T marine carbonates exhibit anomalous $\mathrm{Mn} / \mathrm{Al}$ ratios relative to normal Pacific ocean carbonates. III. Lunar Planet. Sci., 20:464-465.

Laul, J. C., 1979. Neutron activation analysis of geological materials. Atomic Energy Rev., 17:603-695.

Leg 116 Shipboard Scientific Party, 1987. Collisions in the Indian Ocean. Nature, 330:519-521.

Liu, Y.-G., Miah, M.R.U., and Schmitt, R. A., 1988. Cerium: a chemical tracer for paleo-oceanic redox conditions. Geochim. Cosmochim. Acta , 52:1361-1371.

Liu, Y.-G., and Schmitt, R. A., 1984. Chemical profiles in sediment and basalt samples from Deep Sea Drilling Project Leg 74, Hole 525A, Walvis Ridge. In Moore, T. C., Jr., Rabinowitz, P. D., et al., Init. Repts. DSDP, 74: Washington (U.S. Printing Office), 713-730.

Michel, H. V., Asaro, F., Alvarez, W., and Alvarez, L. W., 1985. Elemental profile of iridium and other elements near the Cretaceous/ Tertiary boundary. In Heath, G. R., Burckle, L. H., et al., Init. Repts. DSDP, 86: Washington (U.S. Printing Office), 533-538.

Palmer, M. R., 1985. Rare earth elements in foraminifera tests. Earth Planet. Sci. Lett., 73:285-298.

Sadasivan, S., Nambi, K.S.V., and Murali, A. V., 1981. Geochemical and thermoluminescence studies of the shales from the off-shore drill core, west coast of India. Mod. Geol., 8:13-22.

Wang, Y.-L., Liu, Y.-G., and Schmitt, R. A., 1986. Rare earth element geochemistry of South Atlantic deep sea sediments: Ce anomaly change at $\sim 54 \mathrm{My}$. Geochim. Cosmochim. Acta , 50:1337-1355.

Date of initial receipt: 24 February 1989

Date of acceptance: 15 January 1990

Ms 115B-180 